\title{
MARINE RESERVE BENEFITS LOCAL FISHERIES
}

\author{
Garry R. Russ,${ }^{1,6}$ Angel C. Alcala, ${ }^{2}$ Aileen P. Maypa,${ }^{3}$ Hilconida P. Calumpong,${ }^{4}$ \\ and Alan T. White 5 \\ ${ }^{1}$ School of Marine Biology and Aquaculture, James Cook University, Townsville, Queensland, 4811, Australia \\ ${ }^{2}$ Silliman University Angelo King Center for Research and Environmental Management, Silliman University, \\ Dumaguete City, 6200, Philippines \\ ${ }^{3}$ Project Seahorse Foundation, No. 12 Espina Compound, V. Rodriguez, Cebu City, 6000, Philippines \\ ${ }^{4}$ Silliman University Marine Laboratory, Dumaguete City, 6200, Philippines \\ ${ }^{5}$ Coastal Resource Management Project, Fifth Floor, CIFC Towers, North Area, Cebu City, 6000, Philippines
}

Abstract. The utility of no-take marine reserves as fisheries-management tools is controversial. It is hypothesized that marine reserves will help to sustain fisheries external to them by becoming net exporters of adults (the "spillover effect") and net exporters of propagules (the "recruitment effect"). Local fishery benefits from spillover will likely generate support from fishing communities for marine reserves. We used underwater visual census to show that biomass of Acanthuridae (surgeonfish) and Carangidae (jacks), two families of reef fish that account for $40-75 \%$ of the fishery yield from Apo Island, Philippines, tripled in a well-protected no-take reserve over 18 years (1983-2001). Biomass of these families did not change significantly over the same period at a site open to fishing. The reserve protected $10 \%$ of the total reef fishing area at the island. Outside the reserve, biomass of these families increased significantly closer to (200-250 m) than farther away from $(250-500 \mathrm{~m})$ the reserve boundary over time. We used published estimates of fishery catch and effort, and fisher interviews (creel surveys) to show that the total catch of Carangidae and Acanthuridae combined at Apo Island was significantly higher after (19852001) than before (1981) reserve establishment. Hook-and-line catch per unit effort (CPUE) at the island was 50\% higher during 1998-2001 (reserve protected 16-19 years) than during 1981-1986 (pre-reserve and early phases of reserve protection). Total hook-and-line effort declined by $46 \%$ between 1986 and 1998-2001. Hook-and-line CPUE of Acanthuridae was significantly higher close to (within $200 \mathrm{~m}$ ) than far from the reserve. CPUE of Carangidae was significantly higher away from the reserve, possibly reflecting a local oceanographic effect. The benefits of the reserve to local fisheries at the island were higher catch, increased catch rate, and a reduction in fishing effort. The fishery and tourism benefits generated by the reserve have enhanced the living standard of the fishing community.

Key words: Acanthuridae; Carangidae; catch rates; coral reef fish; fisheries management; fishery yields; marine reserves, benefits to local fisheries; Philippines (Apo Island); spillover effect.

\section{INTRODUCTION}

No-take marine reserves are areas of the marine environment in which all forms of extraction by humans, primarily fisheries, are banned permanently (Roberts and Polunin 1991, Allison et al. 1998, Roberts and Hawkins 2000, NRC 2001, Gell and Roberts 2002). Marine reserves are often promoted as potentially the most useful management tools available to overcome important problems facing the marine environment. These problems include loss of biodiversity (Bohnsack and Ault 1996, Allison et al. 1998, Dayton et al. 2000, Roberts and Hawkins 2000, Jackson et al. 2001), alteration of trophic structure of ecosystems (Pauly et al. 1998, 2002, Jackson et al. 2001), and chronic overfishing worldwide (Pauly et al. 1998, 2002, Roberts and Hawkins 2000, Jackson et al. 2001, NRC 2001, Roberts et al. 2001, Gell and Roberts 2002, Russ and

Manuscript received 17 March 2003; revised 3 June 2003; accepted 7 June 2003. Corresponding Editor: P. K. Dayton.

${ }^{6}$ E-mail: garry.russ@jcu.edu.au
Zeller 2003). Marine reserves also have other important economic and social benefits, such as enhancing tourism (Kelleher et al. 1995). In the past decade studies of marine reserves as management tools to address biodiversity and fisheries questions have produced a burgeoning literature (Roberts and Polunin 1991, Roberts and Hawkins 2000, NRC 2001, Gell and Roberts 2002, Russ 2002, Gerber et al. 2003). However, the utility of no-take marine reserves as fisheries management tools remains controversial (NRC 2001, Hilborn 2002). The main expectations of marine reserves are that they will maintain biodiversity and natural ecosystem states, and sustain fisheries external to them by becoming net exporters of adults (the "spillover effect") and net exporters of propagules (the "recruitment effect") (Russ 2002). The spillover effect is generally expected to operate locally, on spatial scales of hundreds of metres to kilometres for reef fish (Roberts and Polunin 1991, McClanahan and Mangi 2000, Roberts et al. 2001, Gell and Roberts 2002, Russ 2002, Gerber et al. 2003). The recruitment effect is expected to operate on the scales 
of dispersal of pelagic larvae, that is at least tens of kilometres (Palumbi 2001, Cowen 2002, James et al. 2002, Gaines et al. 2003). However, unequivocal evidence to support these expectations has been lacking (Russ 2002).

Successful implementation of marine reserves requires the strong support of local fishing communities (Russ and Alcala 1999). If such communities cannot perceive fishery benefits in the immediate area of the reserve, such as those caused by spillover, they are far less likely to support reserves as a fisheries management tool (Russ and Alcala 1996, Roberts et al. 2001). This is true, even if such reserves eventually maintain or even enhance fisheries at larger spatial scales by the recruitment effect. However, clear demonstrations of spillover affecting local fishery catches and catch rates over appropriate time scales are rare, and results are equivocal (Cole et al. 2000, Davidson 2001, McClanahan and Mangi 2000, Roberts et al. 2001, Galal et al. 2002, Kelly et al. 2002, Russ 2002). In fact, no study has demonstrated spillover (net export of adults) from a marine reserve unequivocally (Russ 2002). This is due partly to lack of appropriate experimental designs (e.g., lack of information on spatial abundance patterns, spatial catch rate, and movement patterns of targeted species before and after reserve establishment). It is also likely due to the fact that few studies have investigated spillover from reserves over longenough time periods to see the effect develop fully.

Studies of spillover from coral-reef reserves are generally of a decade or less. For example, studies of McClanahan and Kaunda-Arara (1996) and McClanahan and Mangi (2000) in Kenya, Russ and Alcala (1996) in the Philippines, Roberts et al. (2001) in St. Lucia, and Galal et al. (2002) in Egypt, spanned 6, 7, 10,5 , and 5 years, respectively. All of these studies produced evidence consistent with spillover. However, if many species of coral-reef fish are relatively long lived (e.g., maximum potential longevities of the order of 10-40 years for many species; Choat and Axe 1995, Cappo et al. 2000, Choat and Robertson 2002), spillover from many coral-reef reserves may well take decades to develop fully. The only study to date to investigate spillover of tropical reef fish from a reserve over decadal time scales is that of Roberts et al. (2001) in Florida (USA). They showed that export of fish to hook-and-line fisheries outside the Merritt Island notake reserve took 9,27 , and 31 years to begin to develop for three species of long-lived reef fish (longevity range 15-70 years).

We have monitored changes in biomass of Acanthuridae (surgeonfish) and Carangidae (jacks) in a wellprotected no-take reserve occupying $10 \%$ of the coralreef fishing area at Apo Island, Philippines, and at a site open to fishing on the island, regularly for almost two decades (1983-2001). These two families of reef fish were chosen for detailed study because they are the major component of reef-fish catch at Apo island, accounting for 40-75\% of fishery yields (Maypa et al. 2002). In addition we have quantified the fishery catch of these two families of reef fish, and hook-and-line catch per unit effort (CPUE) in pre-reserve (1981) and post-reserve (1985-2001) conditions over two decades. We have also quantified spatial distribution of both fish biomass, and hook-and-line CPUE, to show the spatial extent of spillover. The study demonstrates clear local fishery benefits generated by the reserve.

The specific questions we address are:

1) Does the biomass of Acanthuridae and Carangidae, families of reef fish heavily targeted by the reef fishery, increase over decadal time scales in the notake reserve, but not at a site open to fishing?

2) Is there evidence that biomass of these reef-fish families builds up outside the reserve closer to, than further from, the reserve boundary over decadal time scales?

3) Is there evidence that total catch of these families, and hook-and-line catch rates (CPUE), increase through time in the presence of a well-protected reserve?

4) Is there evidence that hook-and-line effort decreases through time in the presence of a well-protected reserve?

5) Is there evidence that hook-and-line CPUE outside the reserve is higher closer to, than further from, the reserve boundary for Acanthuridae and Carangidae?

\section{Methods}

Study site

Apo Island, Philippines, is southeast of Negros $\left(9^{\circ} 4^{\prime}\right.$ $\left.\mathrm{N}, 123^{\circ} 17^{\prime} \mathrm{E}\right)$. It is a mainland island of $0.7 \mathrm{~km}^{2}$ surrounded by $1.06 \mathrm{~km}^{2}$ of fringing coral reef to the 60 $\mathrm{m}$ isobath $\left(0.7 \mathrm{~km}^{2}\right.$ to the $20-\mathrm{m}$ isobath). The island had a no-take marine reserve established in 1982. The Apo reserve is a $0.45-\mathrm{km}$ section $(\sim 10 \%$ of the coralreef area) of the southeastern side of the island (Fig. 1). The area of the reserve to $500 \mathrm{~m}$ from shore is 22.5 ha. The reef crest is at a depth of 6-7 $\mathrm{m}$ and there is a high percentage cover of hard corals on the reef crest and slope. The nonreserve site at Apo Island has a crest at a depth of 5-7 m. The crest and slope are consolidated limestone overlying a base of volcanic rock. There is a relatively high percentage cover of living corals, particularly soft corals (Russ and Alcala 1998). The Apo reserve (= sanctuary) was protected by the resident community from 1982, although the legal framework for the protected area was not in place until August 1985 (Russ and Alcala 1999, White et al. 2002). Protection of the marine reserve has been very successful, with a local marine-management committee overseeing enforcement during the period 1982-2001. The nonreserve area was open to municipal fishing (hook and line, gill nets, bamboo traps, and spears) throughout the study. A marine management plan for 


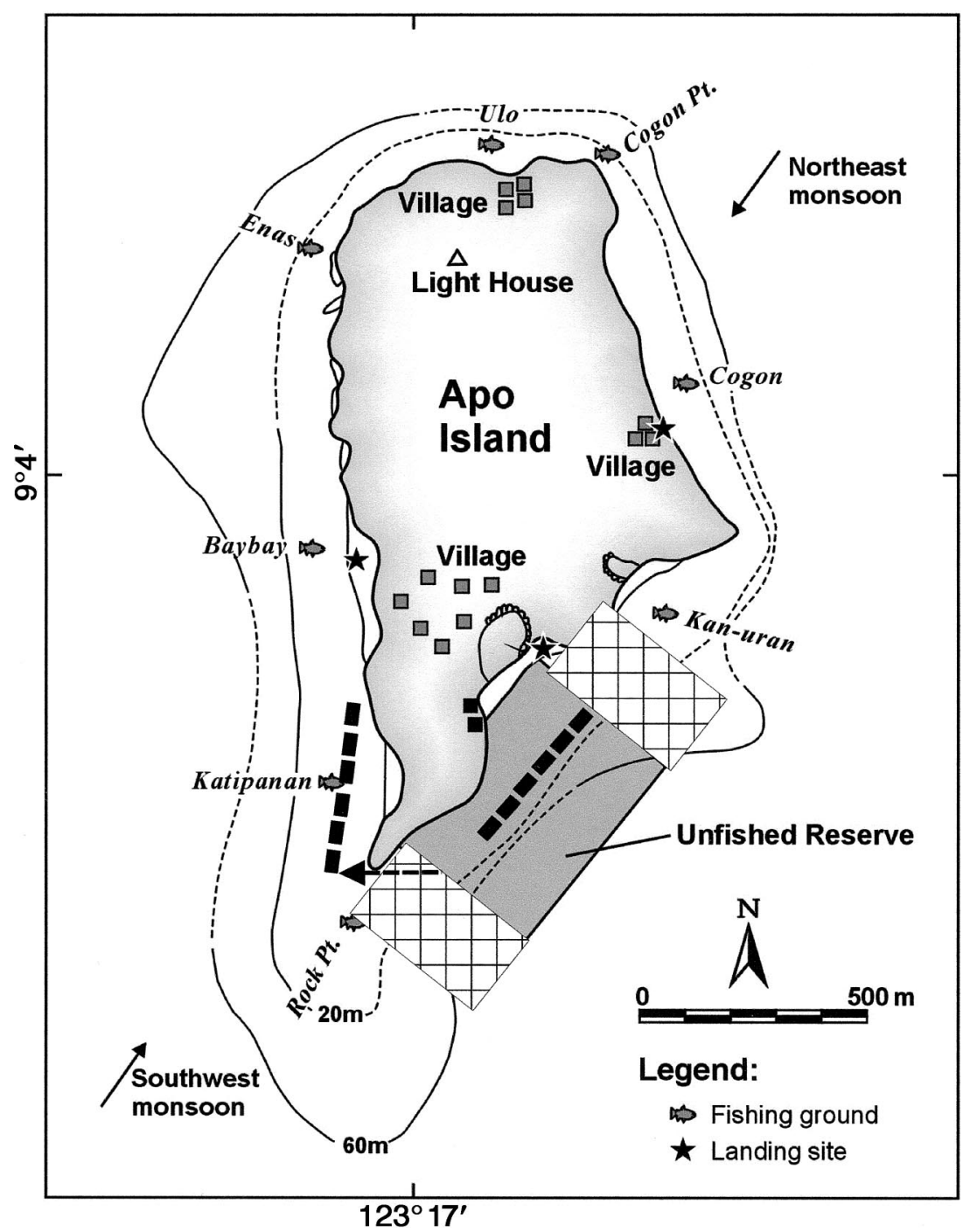

FIG. 1. Map of Apo Island, Philippines, showing the location of the no-take reserve (shaded), the positions of the replicate underwater visual census (UVC) plots in the reserve and in the fished nonreserve site at Katipanan (solid black rectangles), the major fishing grounds around the island, and the major fish-landing sites. The cross-hatching shows the area enclosed by $200-\mathrm{m}$ lines extending straight out from each side of the reserve. The arrow from the southern boundary of the unfished reserve directly to the first UVC replicate plot at the nonreserve site is $200 \mathrm{~m} \mathrm{long}$.

Apo Island was introduced in 1986 (Russ and Alcala 1999, White et al. 2002). This banned all forms of destructive fishing gears (explosives, drive nets, smallmesh nets, poisons) from the entire island, and banned fishing by nonresidents. Thus from 1986 onwards, only traditional fishing methods were used outside the reserve (= sanctuary), and only residents fished the reef. The major activity of the 500 residents is fishing, with the nonreserve area fished by $\sim 200$ fishers during the study period. The northeast and southwest monsoon seasons dominate the local fishing patterns. A large part of the catch is taken during the southwest monsoon (June-September) and the interim calm periods (AprilMay and October) between the monsoons (Bellwood 1988). Most of the Carangidae (jacks) at Apo Island are caught on the north of the island, far from the reserve, during the southwest monsoon and the calm periods (Bellwood 1988, Maypa et al. 2002). This is also the location where the mainstream currents first hit the reef (Bellwood 1988, Maypa et al. 2002). The reserve is one of the oldest and best-protected reserves in the world (Russ and Alcala 1999). The local fishing community has maintained effective protection from 1982 to date (2003) (Russ and Alcala 1999, White et al. 2002).

\section{Method of visual census}

Estimates of biomass of Acanthuridae (surgeonfish) and Carangidae (jacks) were made at the reserve and a nonreserve (fished) site in December or November 
TABle 1. Details of estimates of catch of Acanthuridae and Carangidae between 1980/1981 and 2001 at Apo Island, Philippines.

\begin{tabular}{|c|c|c|c|c|c|}
\hline Study & Period & $\begin{array}{l}\text { Before or } \\
\text { after reserve } \\
\text { established }\end{array}$ & $\begin{array}{c}\text { Variates } \\
\text { measured } \dagger\end{array}$ & $\begin{array}{c}\text { Areas } \\
\text { surveyed }\end{array}$ & Methods used \\
\hline $\begin{array}{l}\text { Alcala and } \\
\text { Luchavez } \\
\text { (1981) }\end{array}$ & $\begin{array}{l}\text { May } 1980- \\
\text { March } \\
\text { 1981‡ }\end{array}$ & before & $\begin{array}{l}\text { C, median } \\
\text { E, and } \\
\text { CPUE }\end{array}$ & $\begin{array}{l}\text { fish market, } \\
\text { landing sites }\end{array}$ & $\begin{array}{l}\text { Questionnaire interviews with fishers and } \\
\text { direct observations; } 49 \text { days of surveys, } \\
\text { most days market day (Wednesday). } \\
\text { Type of fish, gear used, hours fished, } \\
\text { weight of catch. }\end{array}$ \\
\hline $\begin{array}{l}\text { White and } \\
\text { Savina } \\
(1987)\end{array}$ & $\begin{array}{l}\text { April 1985- } \\
\text { March } \\
1986\end{array}$ & after & $\begin{array}{l}\mathrm{C} \text {, mean } \mathrm{E} \text {, } \\
\text { and CPUE }\end{array}$ & landing sites & $\begin{array}{l}\text { Daily estimates made by seven fish dealers/ } \\
\text { volunteers. Type of fish, gear used, hours } \\
\text { fished, weight of catch. }\end{array}$ \\
\hline $\begin{array}{c}\text { Bellwood } \\
\quad(1988)\end{array}$ & $\begin{array}{c}\text { Jan.-Dec. } \\
1986\end{array}$ & after & $\mathrm{C}$ & fish market & $\begin{array}{l}\text { Every market day (Wednesday). Researcher } \\
\text { recorded species of fish, gear used, } \\
\text { weight of catch. Data converted to annu- } \\
\text { al estimates. }\end{array}$ \\
\hline $\begin{array}{l}\text { H. P. Calum- } \\
\text { pong, un- } \\
\text { published } \\
\text { data }\end{array}$ & $\begin{array}{l}\text { June } 1997- \\
\text { Sept. } \\
1998 \neq\end{array}$ & after & $\begin{array}{l}\mathrm{C}, \text { mean } \mathrm{E} \text {, } \\
\text { and CPUE }\end{array}$ & $\begin{array}{l}3 \text { main landing } \\
\text { sites }\end{array}$ & $\begin{array}{l}\text { Daily creel surveys by research assistant. } \\
\text { Species of fish, gear used, hours fished, } \\
\text { weight of catch.§ }\end{array}$ \\
\hline $\begin{array}{l}\text { Maypa et al. } \\
(2002)\end{array}$ & $\begin{array}{c}\text { Jan.-Dec. } \\
2000\end{array}$ & after & $\begin{array}{l}\mathrm{C}, \text { mean } \mathrm{E} \text {, } \\
\text { and } \mathrm{CPUE}\end{array}$ & $\begin{array}{l}3 \text { main landing } \\
\text { sites }\end{array}$ & $\begin{array}{l}\text { Creel surveys (three randomly chosen days } \\
\text { per week, converted to weekly estimate) } \\
\text { by researcher or assistant. Species of } \\
\text { fish, gear used, hours fished, weight of } \\
\text { catch (weighing scales)§ }\end{array}$ \\
\hline $\begin{array}{l}\text { Maypa et al. } \\
(2002)\end{array}$ & $\begin{array}{c}\text { Jan.-Dec. } \\
2001\end{array}$ & after & $\begin{array}{l}\mathrm{C}, \text { mean } \mathrm{E} \text {, } \\
\text { and CPUE }\end{array}$ & $\begin{array}{l}3 \text { main landing } \\
\text { sites }\end{array}$ & As above for Jan.-Dec. 2000.§ \\
\hline
\end{tabular}

$\dagger \mathrm{C}=$ catch; $\mathrm{CPUE}=$ catch per unit effort; $\mathrm{E}=$ hook-and-line effort.

†xtrapolated to annual estimate.

$\S$ At Apo Island, fishers land their catch in many different sites, making it difficult to record every fish landing. Three major landing sites were monitored in 1997/1998, 2000, and 2001 (Fig. 1: black stars). The estimated annual catch for these years was adjusted by adding $10 \%$ to the actual values for both reef/reef-associated and non-reef catches to account for this. This figure of $10 \%$ was based on the mean estimates given by fishers through interviews in $2000(10.2 \pm 0.29 \%$ [mean \pm $1 \mathrm{SE}], n=55$ fishers) and $2001(10.5 \pm 0.41 \%, n=55$ fishers $)$ as the amount of catch not recorded in surveys.

of each year from 1983 through 2001 except for the years 1984, 1986-1987, and 1996. These two families of reef fish account for $40-75 \%$ of the total fish yield from the island (Maypa et al. 2002). The method of underwater visual census (UVC) has been published elsewhere (Russ and Alcala 1998). Six 1000-m² replicate areas of reef slope were censused in the reserve (6-17 $\mathrm{m}$ depth) and at the fished nonreserve site (9$17 \mathrm{~m}$ ) on each sampling occasion. The observer (G.R. Russ), the method of UVC, and the position of the replicates were the same during 1983-2001 (Fig. 1) (except that some replicate areas at the nonreserve site differed between 1983 and all other times). The abundances of small species of Acanthuridae (Ctenochaetus, small Acanthurus, small Naso) were estimated cumulatively in $\log _{4}$ abundance categories in a census area. These categories were: Category $1=1$ fish, Category $2=2-4$ fish, Category $3=5-16$ fish, Category $4=$ 17-64 fish, Category $5=65-256$ fish, Category $6=$ 257-1024 fish, Category $7=1025-4096$ fish. Simultaneously, actual counts and estimates of total length ( $\pm 5 \mathrm{~cm}$ ), of large Acanthuridae (large Acanthurus, large Naso) and Carangidae were made. Juveniles $(<10$ $\mathrm{cm}$ long) were not counted. An estimate of biomass for those species for which density and size-structure data were available was constructed using published length- mass relationships for the species or closely related species (Froese and Pauly 1997). Length estimates were not made for individuals of small species of Acanthuridae. These species thus lacked size-structure data. An estimate of average length of a fish in the genus was made and converted to an average mass from published length-mass relationships (Froese and Pauly 1997). Abundance of these small species of Acanthuridae was converted to approximate estimates of density by using midpoints of abundance categories. Density and average mass estimates were then used to estimate biomass per unit area. Spatial distribution of fish biomass over time at the nonreserve site was estimated using the methods described in Russ and Alcala (1996). Estimates of biomass were made for each replicate 50 $\times 20 \mathrm{~m}$ plot in the nonreserve area (Fig. 1). These were averaged for the period 1985-1988 (early phase of reserve protection) and 1990-2001 (mid- to late phase of reserve protection). The 1983 nonreserve data were excluded in this analysis.

\section{Estimates of catch and catch per unit effort}

Annual catch of Acanthuridae and Carangidae, and mean annual hook-and-line catch per unit effort (CPUE), were estimated once before, and several times after, reserve establishment (Table 1). All fishers used 
hook and line, and this gear accounted for most of the catch during the study period (Maypa et al. 2002). Catches of reef fish and reef-associated fish from within the $60-\mathrm{m}$ isobath line were recorded in all studies (Table 1). Catch surveys from 1997/1998 to 2001 used fishlanding forms that recorded fishing ground (Fig. 1). This allowed estimates of spatial variations in CPUE around the island.

To collect information on the perceptions of the fishers regarding the potential effect of the marine reserve on local fish catch, fishers were interviewed in 1986, 1992, and 2000 at Apo Island (Walmsley 2000; A. T. White and H. Calumpong, 1992 unpublished report [Earth Watch Institute, Maynard, Massachusetts, USA]). Fishers were asked if they believed if their fish catch had increased, decreased, had not changed, or if they did not know.

\section{Data analysis}

Statistical comparisons of biomass of Acanthuridae and Carangidae at the reserve and nonreserve sites over the 14 times were made using univariate, repeatedmeasures ANOVA. The three factors in this analysis were "reserve" (2 levels), "plots" (6 levels) nested within each reserve and nonreserve site (a random factor), and the repeated measure "time" with 14 levels. A repeated-measure ANOVA was used because the same plots were sampled each year. A single "missing data" point (only five replicate plots were taken at Apo nonreserve in 1983) was calculated by unweighted means analysis (Winer 1971). Before proceeding with the ANOVA, the data were examined for homogeneity of variance $(P<0.05)$ by Cochrans test (Underwood 1981), for excessive skewness and outliers by examining Box plots, for strong positive correlations between means and variances, and for normality. Data were transformed $\left(\log _{10}(x+1)\right)$. The assumption of sphericity in univariate, repeated-measures ANOVA was overcome by using Greenhouse-Geisser adjusted $P$ values for the Reserve $\times$ Time interaction. The spatial distribution of biomass in the nonreserve site (biomass in each of the six $50 \times 20 \mathrm{~m}$ replicate plots; see Fig. 1) in the early (1985-1988) and late (1990-2001) phases of reserve protection was compared using a chisquare test.

Catch of Acanthuridae and Carangidae combined before reserve establishment (1981) was compared to that after reserve establishment (1985-2001) by a onetailed $t$ test. Hook-and-line catch per unit effort (CPUE) in 1981-1986 (early phase of reserve establishment) was compared to that in 1998-2001 (late phase of reserve establishment) by a two-tailed $t$ test. Insufficient hook-and-line effort data were collected in the early phases of reserve establishment to allow formal statistical comparisons with effort measures taken in the late phase of reserve establishment. Hook-and-line CPUE close to (within $200 \mathrm{~m}$ ) and far from the reserve in the late phase of reserve establishment (2000/2001) was compared by $t$ tests for both Acanthuridae and Carangidae.

\section{RESUlts}

The biomass of Acanthuridae (surgeonfish) and Carangidae (Jacks) tripled inside the reserve over 18 years of protection from fishing (Fig. 2a). There was no clear pattern of change in biomass at the fished site over the same period (Fig. 2b) (repeated-measures ANOVA, Protection $\times$ Time interaction $F_{13,130}=4.35, P<$ $0.0001)$. This is consistent with the hypothesis that the removal of fishing caused the increase in fish biomass in the reserve. Outside the reserve, biomass of these families of reef fish increased significantly closer to $(200-250 \mathrm{~m})$ than further away from $(250-500 \mathrm{~m})$ the reserve boundary over time (Fig. 2c) (chi-square $=$ 12.68 , df $=5, P<0.05$ ). This pattern of higher abundance within 200-250 $\mathrm{m}$ of the reserve first appeared around 1990, $\sim 8$ years after the reserve was established (Fig. 2c).

Total catch of Acanthuridae and Carangidae combined was significantly higher after than before reserve establishment (Fig. 3a) (one-tailed $t$ test, $t=6.35$, df $=4, P<0.005)$. A more conservative analysis of these data is a comparison of the catch before and in the early phases of reserve development (1981-1986) with the catch after biomass of Acanthuridae and Carangidae had trebled in the reserve (1998-2001). This comparison shows that mean catch of these reef fish declined by $2.1 \%$. (The total annual catch (mean $\pm 1 \mathrm{SE}$ ) for 1981-1986 ranged from $13500 \pm 3470 \mathrm{~kg}[n=3$ replicate years] to $13200 \pm 1120 \mathrm{~kg}[n=3$ replicate years]). However, this still suggests strongly that the reserve enhanced the local fishery, since $10 \%$ of the fishing area was removed. Hook-and-line catch per unit effort (CPUE) (Fig. 3b) was 50\% higher in 1998-2001 (mean CPUE $1.26 \mathrm{~kg} \cdot$ person $^{-1} \cdot \mathrm{h}^{-1}$ ) than in 1981-1986 (mean CPUE $0.84 \mathrm{~kg} \cdot$ person $\left.^{-1} \cdot \mathrm{h}^{-1}\right)(t=2.99$, df $=54$, $P=0.004)$. Total hook-and-line effort (Fig. 3c) declined by 46\% between 1986 (19518 h, $n=1$ replicate year) to 1998-2001 (Mean $10360 \mathrm{~h}, n=3 \mathrm{rep}-$ licate years). CPUE of Acanthuridae was significantly higher close to (within $200 \mathrm{~m}$ ) than far from the reserve (Fig. 3d) $(t=3.85$, df $=662, P=0.0001)$. CPUE of Carangidae was significantly higher away from the edges of the reserve (Fig. 3d) $(t=2.39$, df $=662, P=$ 0.017).

The biological data are largely consistent with perceptions of the status of the fishery by the fishing community (Table 2). A very high percentage (67-100\%) of fishers interviewed in 1986, 1992, and 2000 believed that fish catch at Apo Island had increased. These data, collected independently of the fishery data in Figs. 2 and 3 , show that the local fishing community believes that the fishery has been improved by the presence of the reserve. 


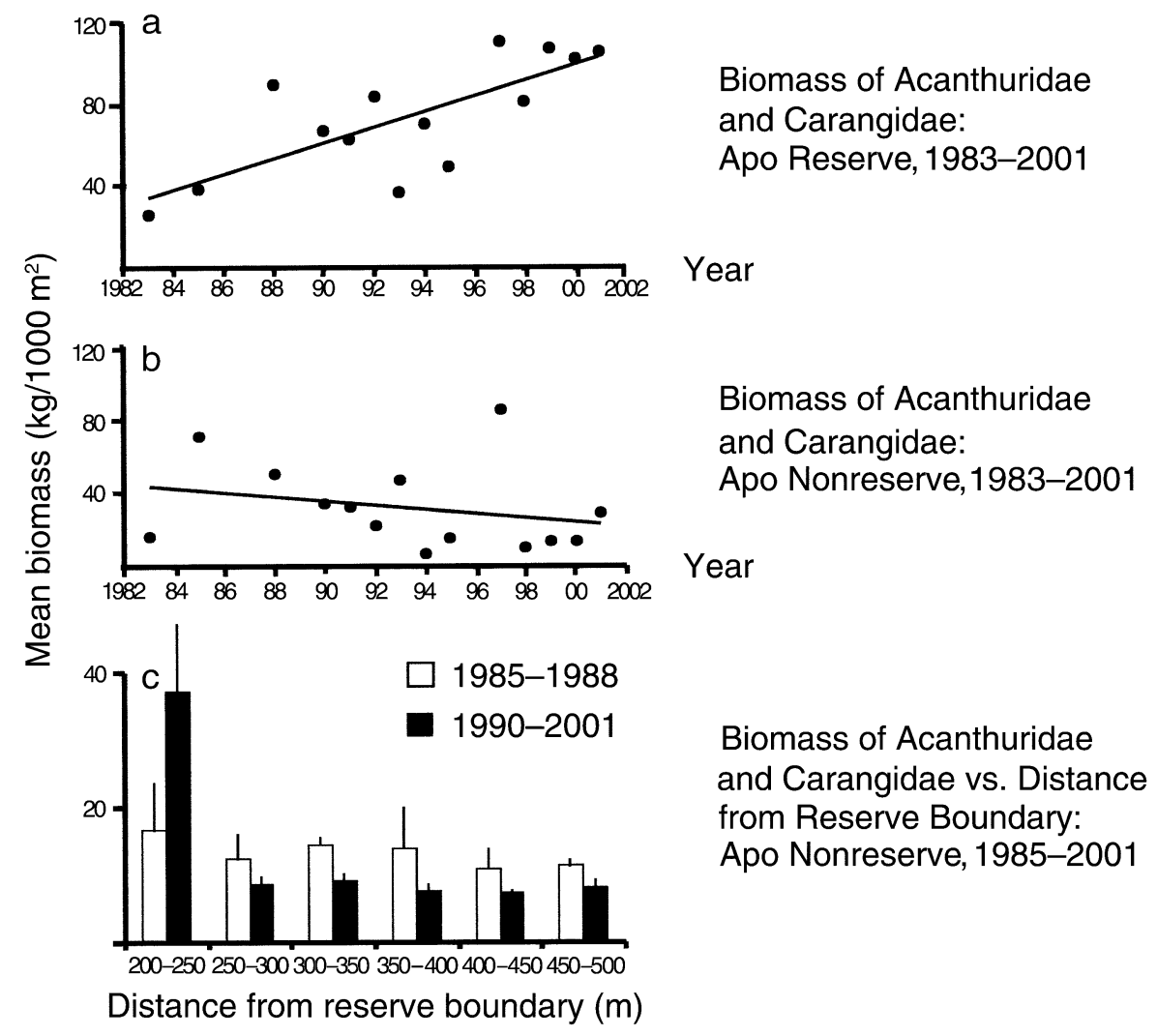

FIg. 2. Estimates of biomass of Acanthuridae and Carangidae at Apo Island, Philippines. Underwater visual census (UVC) estimates of biomass (a) in the no-take reserve and (b) in the the fished nonreserve 1983-2001. (c) Spatial distribution of biomass of these families of reef fish outside the reserve at different distances from the reserve boundary in the early (1985$1988)$ and late (1990-2001) phases of protection of the no-take reserve. Data are means and 1 SE.

\section{DISCUSSION}

The fishery benefits that developed at Apo Island over the 20-year study were higher catch rates, less fishing effort, and enhancement or at least maintenance of total catch of Acanthuridae and Carangidae. Even a conservative interpretation of our data would be that for a reserve to benefit local fisheries it does not have to enhance catch, just catch rates.

The improved catch rates and reduced fishing effort at Apo Island have arisen for at least three reasons. The first of these is spillover from the reserve. Several lines of evidence support the contention that the fishery has benefited from spillover. Firstly, there is the fact that outside the reserve, biomass of Acanthuridae and Carangidae increased significantly closer to (200-250 $\mathrm{m})$ than further away from $(250-500 \mathrm{~m})$ the reserve boundary over time. This effect first appeared $\sim 8 \mathrm{yr}$ after reserve establishment. Secondly, hook-and-line catch per unit effort (CPUE) of Acanthuridae was significantly higher close to (within $200 \mathrm{~m}$ ), than far from, the reserve. The data from underwater visual census (UVC) and spatial CPUE of Acanthuridae both suggest that the spatial scale of the fishery benefit from spillover from the Apo reserve is of the order of a few hundred meters. The difference in spatial CPUE be- tween the two families of reef fish may reflect the fact that the Acanthuridae is generally far less mobile than the Carangidae, and thus more likely to show spillover (DeMartini 1993). In addition, most of the Carangidae at Apo Island are caught on the north of the island, far from the reserve, during the southwest monsoon and the calm periods (Bellwood 1988, Maypa et al. 2002). The north of the island is also the location where the mainstream currents first hit the reef (Bellwood 1988, Maypa et al. 2002). The spatial variations in CPUE of Carangidae are consistent with this information. Thirdly, the percentage of Acanthuridae and Carangidae in the fisheries catch from the island increased from $42.5 \%$ in $1980 / 1981$ (Alcala and Luchavez 1981) to a mean of $73.5 \%$ in 2000/2001 (Maypa et al. 2002). While the latter is circumstantial evidence, it is noteworthy that the fishers appear to have changed their fishing patterns over time (Maypa et al. 2002). Fishers travel off-reef to catch Scombridae (mackerel) and Elopidae (tarpons) with drift gill nets far less frequently than they did in the early 1980 s because reef fish like acanthurids and carangids may have become far more available over time (Maypa et al. 2002).

There are at least two other reasons, in addition to spillover, for the improved catch rates and reduced fish- 


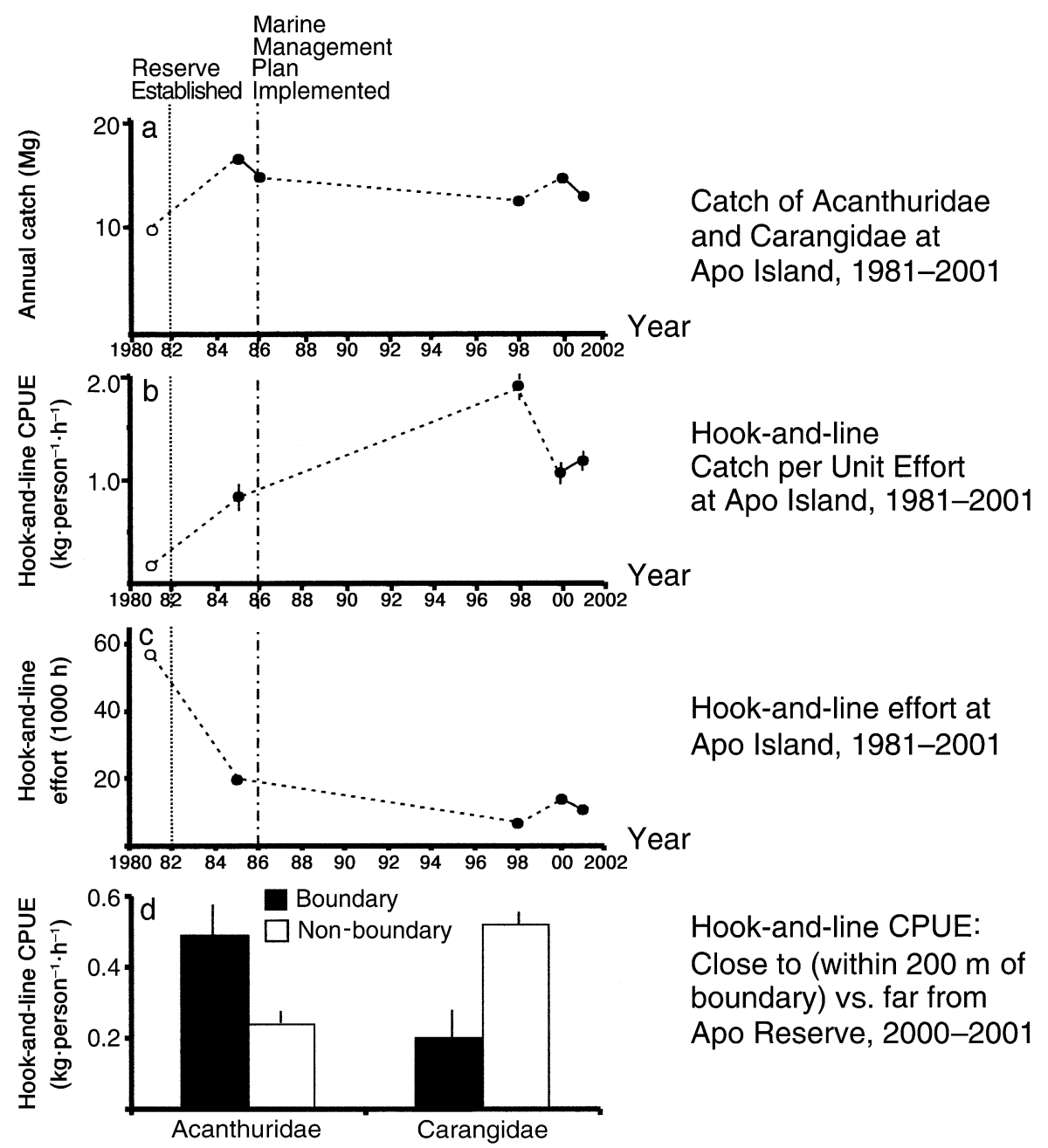

FIg. 3. Catch data for Acanthuridae and Carangidae at Apo Island, Philippines. (a) Total catch of Acanthuridae and Carangidae combined, before and after the establishment of Apo reserve. (b) Catch per unit effort (CPUE) of hook-and-line fisheries, estimated before and after establishment of Apo reserve. (c) Effort of hook-and-line fisheries, estimated before and after establishment of Apo reserve. In (a)-(c), the vertical dotted line indicates the year in which the reserve was established (1982); the vertical dashed line indicates the year of implementation of the Marine Management Plan (1986). Open circles $=$ pre-reserve, solid circles = post-reserve; error bars indicate 1 SE. (d) Hook-and-line CPUE close to (within $200 \mathrm{~m}$ ) and far from the reserve boundary in 2000/2001. Megagrams $(\mathrm{Mg})=$ metric tons $(\mathrm{t})$.

ing effort at Apo Island. In 1986 the fishing community introduced a Marine Management Plan that banned nonresidents from fishing around the island, and also banned a wide range of highly efficient and destructive fishing gears (explosives, poisons, muro-ami push nets, small-mesh nets, spearing on SCUBA) (Russ and Alcala 1999, White et al. 2002) (Fig. 3). In addition, the excellent condition of coral and fish life in the reserve (Russ and Alcala 1998) has attracted substantial tourism to the island. This has generated considerable income into the community (Alcala 1998, White et al. 2002). The economic benefit to the local community of the reserve generated by tourism and fisheries was estimated to be US $\$ 500$ per hectare of reef per year (Alcala 1998). Thus, islanders have to fish less to support their families.
The trends in catch, effort, and CPUE are subject to a range of potential limitations and influences. Fishing effort, particularly hook-and-line effort (Fig. 3c), has declined over the study. Clearly this will influence estimates of catch over time. Fishing gears used by fishers have changed slightly over the period. Drift gill nets were used commonly in 1980/1981 (Alcala and Luchavez 1981). Such drift gill nets were not used after 1999/2000 (L. Pascobello-Rhodes [Apo Island resident], personal communication). The decline of nonreef catch such as elopids and scombrids from 1980/ 1981 to 2000/2001 (Maypa et al. 2002) coincided with less frequent use of these drift gill nets. Fish traps, a common fishing gear in the period 1980-1986 (Alcala and Luchavez 1981, White and Savina 1987, Bellwood 1988) were not used at all during 2000 , but were re- 
TABLE 2. Results of three surveys (1986, 1992, 2000) of Apo Island (Philippines) fishers asked whether their fish catch had changed since the establishment of the nearby marine no-take reserve.

\begin{tabular}{lcrr}
\hline \hline & 1986 & 1992 & 2000 \\
\hline Number of interviewees & 12 & 12 & 21 \\
Interviewee responses (\%) & & & \\
$\quad$ Fish catch increased & 92 & 100 & 67 \\
Fish catch decreased & 0 & 0 & 14 \\
No change in fish catch & 8 & 0 & 14 \\
Do not know & 0 & 0 & 5 \\
\hline
\end{tabular}

Notes: The table shows the percentage of interviewees responding in each way. Data are from Walmsley (2000) and from A.T. White and H. Calumpong (unpublished report [1992, Earthwatch Institute, Maynard, Massachusetts, USA]).

introduced into the fishery in 2001. These shifts in gear types will clearly influence catch and catch composition. However, hook-and-line fishing has remained the principal fishing gear throughout the study, ensuring that trends in hook-and-line CPUE reflect the major temporal trends in the reef fishery.

In addition, slight variations in methods used to collect data in 1980/1981 (Alcala and Luchavez 1981), 1985/1986 (White and Savina 1987), 1986 (Bellwood 1988), 1997/1998 (H. P. Calumpong), and 2000/2001 (A. P. Maypa, A. C. Alcala, and G. R. Russ) may have influenced comparisons of catch, effort and CPUE (Table 1). All studies except that of Bellwood (1988) used fisher interviews and a creel-survey-type approach on the Island. Bellwood (1988) estimated fish catch from records of weekly fish landings at a fish market on the mainland, near Apo Island. The initial estimates of hook-and-line fishing effort made by Alcala and Luchavez (1981) may well have been overestimates. This is why these data were not used in any formal statistical comparisons of effort over time. Furthermore, annual catch and CPUE will clearly vary due to environmental changes from year to year. Most of these limitations of the study were either difficult or impossible to overcome. However, these variations in fishing gears and data-collection methods over time do not preclude useful inferences about temporal trends in fishery catch and CPUE, particularly CPUE of the main fishing gear, hook and line. Of greatest importance is the point that even in the presence of contemporaneous changes in fishing practices, data-collection methods and a shift in management plan in 1986, we were still able to detect an effect of the reserve on the local fishery.

Studies of spillover of reef fish are of three main types (Russ 2002). Firstly, there are those that model spillover (e.g., Polacheck 1990, Russ et al. 1992, DeMartini 1993). Secondly, empirical estimates of abundance of target species, and catch and CPUE of fisheries, adjacent to reserves (or across a gradient from reserve to fished areas) over time (e.g., McClanahan and Kaunda-Arara 1996, Rakitin and Kramer 1996, Russ and Alcala 1996, McClanahan and Mangi 2000,
Davidson 2001, Roberts et al. 2001, Galal et al. 2002, Kelly et al. 2002). Thirdly, many studies have measured movement patterns of fish near and across reserve boundaries by tagging (e.g., Holland et al. 1993, Zeller and Russ 1998, Kramer and Chapman 1999, Cole et al. 2000, Eristhee and Oxenford 2001). Modeling and tagging studies related to spillover have been reviewed extensively elsewhere (e.g., Roberts and Polunin 1991, Roberts and Hawkins 2000, NRC 2001, Gell and Roberts 2002, Russ 2002, Botsford et al. 2003, Gerber et al. 2003). Here we will simply discuss the empirical evidence for higher abundance and CPUE just outside reserves, and shifts in fishery characteristics over time in the presence of reserves.

Empirical evidence for spillover from reserves is usually higher abundance or catch rates of exploited species just outside reserve boundaries, or increase in catch and catch rates in the fishery over time (McClanahan and Kaunda-Arara 1996, Rakitin and Kramer 1996, Russ and Alcala 1996, McClanahan and Mangi 2000, Roberts et al. 2001, Galal et al. 2002). McClanahan and Kaunda-Arara (1996) monitored catch and CPUE close to $(1.5 \mathrm{~km})$ and far away from $(6 \mathrm{~km})$ the Mombasa no-take marine park in Kenya, before and after the establishment of the park. The park removed $65 \%$ of the fishing area used by the closest fishlanding site, and about $65 \%$ of fishers quit that landing site. Although CPUE increased by $110 \%$ at the landing site closest to the park two years after establishment of the no-take marine park, total catch was still 35\% lower than before the park was in place. Note that a neutral no-take park effect would suggest a $65 \%$ lower total catch. McClanahan and Mangi (2000) extended this study of the Mombasa no-take marine park to seven years. They showed that CPUE of fish traps (and mean size of trapped fish) declined as a function of distance from both the southern and northern park boundaries. The southern boundary adjoined the managed Mombasa marine reserve, where fishing by pull seines was banned. On this southern boundary of the no-take marine park, catch per fisher and catch per area increased more than $50 \%$ over time. During a new management phase, the total area closed to fishing was reduced from $65 \%$ to $50 \%$ (McClanahan and Mangi 2000). The total catch from this reef fishery declined by $30 \%$ in this early period of establishment of the no-take marine park. McClanahan and Mangi (2000) used empirical and modeling studies to suggest that tropical fisheries dominated by catches of rabbitfish, emperors, and surgeonfish should be enhanced by closed areas of $\sim 10-$ $15 \%$ of the total area.

Rakitin and Kramer (1996) found that the density of trappable species of reef fish was higher in the Barbados no-take marine reserve. They also showed that trap catches decreased gradually with distance from the center of this reserve. Russ and Alcala (1996) suggested that density of large predatory reef fish increased through time (1983-1993) outside the Apo no-take ma- 
rine reserve, Philippines, close to, but not far from, the reserve boundary. Roberts et al. (2001) showed that the creation of a network of five small no-take marine reserves in St. Lucia increased adjacent catches of artisanal fishers by between 46 and $90 \%$ within five years. They attributed these changes to spillover from the reserves. Galal et al. (2002) reported significant increases in abundance and average size of many targeted species of reef fish in two of five no-take marine reserves in the Egyptian Red Sea, and that CPUE of the adjacent fished areas increased by two thirds over a five-year period. Other evidence includes a significant reduction in catch rate and total catch following the breakdown of protection of a 10-year-old no-take marine reserve at Sumilon Island, Philippines (Alcala and Russ 1990).

Not all studies suggest clear spillover effects. Kelly et al. (2002) found no significant difference in CPUE of lobster pots at the boundary of the Leigh marine reserve in New Zealand, with CPUE at sites $0.3-2 \mathrm{~km}$ and 22-30 km away. Kelly et al. (2002) did argue, however, that pots set near the boundary often had more variable CPUE and caught larger lobsters. Davidson (2001) monitored experimental hook-and-line CPUE of bluecod, Parapercis colias, over a 6.5-year period both inside and outside the Long-Island-Kokomohua reserve in New Zealand. Davidson (2001) recorded a four-fold increase in CPUE over time inside the reserve, but no change in CPUE over time at control sites $1.3-5.6 \mathrm{~km}$ away. Cole et al. (2000) demonstrated limited dispersal of this species, so that if spillover of bluecod does occur from such reserves, it may occur on scales of less than $1 \mathrm{~km}$.

No study has demonstrated spillover (net export) unequivocally. The experimental design to measure spillover unequivocally has yet to be applied at the appropriate scales of time (Russ 2002). For example, in the present study we did not tag fish inside and outside the Apo no-take reserve, before and after reserve establishment, to demonstrate how the reserve may have affected movement patterns through time. The present study is, however, one of only two to produce evidence for the development of spillover over decadal time scales. Our results are consistent with those of Roberts et al. (2001) at Merritt Island reserve in Florida (USA). Roberts et al. (2001) showed that export of fish to hookand-line fisheries outside the Merritt Island no-take reserve took 9,27 , and 31 years to begin to develop for three species of long-lived reef fish.

In conclusion, the fishery benefits of the no-take reserve that developed at Apo Island over the 20-year study were higher catch rates, less fishing effort, and enhancement or at least maintenance of total catch of Acanthuridae and Carangidae. All of these changes in the fishery could be related to improved management of marine resources, with a no-take reserve as the primary mechanism of management. This improved management has resulted in a considerable increase in the standard of living of the local fishing community (Alcala 1998). For local fishing communities to support, or even take responsibility for maintaining, no-take reserves, some clear evidence of local fishery benefits is essential (Russ and Alcala 1996). Apo Island is a model of marine resource management that could help alleviate some of most pressing problems of overfishing and loss of marine biodiversity in both the developing and the developed world.

\section{ACKNOWLEDGMENTS}

This project was partially funded by the United Nations Environment Program (1983), the Great Barrier Reef Marine Park Authority (1985), USAID and Pew Fellowships in Marine Conservation to G. R. Russ, A. C. Alcala and A. T. White. Thanks to D. R. Bellwood, G. P. Jones, and two anonymous reviewers for reading the manuscript. We thank S. F. Walmsley for making available the 2000 data in Table 2 from her Masters thesis.

\section{Literature Cited}

Alcala, A. C. 1998. Community-based coastal resource management in the Philippines: a case study. Ocean and Coastal Management 38:179-186.

Alcala, A. C., and T. Luchavez. 1981. Fish yield of the coral reef surrounding Apo Island, central Visayas, Philippines. Pages 69-73 in R. E. Johannes, J. A. Marsh, Jr., and R. T. Tsuda, editors. Proceedings of the Fourth International Coral Reef Symposium (Manila, The Philippines, 18-22 May 1981). Marine Sciences Center, University of the Phillipines, Quezon City, The Phillipines.

Alcala, A. C., and G. R. Russ. 1990. A direct test of the effects of protective management on abundance and yield of tropical marine resources. Journal du conseil Internationale pour l'Exploration de la Mer 47:40-47.

Allison, G. W., J. Lubchenco, and M. H. Carr. 1998. Marine reserves are necessary but not sufficient for marine conservation. Ecological Applications 8:S79-S92.

Bellwood, D. R. 1988. Seasonal changes in the size and composition of the fish yield from reefs around Apo Island, central Philippines, with notes on methods of yield estimation. Journal of Fish Biology 32:881-893.

Bohnsack, J. A., and J. S. Ault. 1996. Management strategies to conserve marine biodiversity. Oceanography 9:73-82.

Botsford, L. W., F. Michell, and A. Hastings. 2003. Principles for the design of marine reserves. Ecological Applications 13:S25-S31.

Cappo, M., P. Eden, S. J. Newman, and S. Robertson. 2000. A new approach to validation of periodicity and timing of opaque zone formation in the otoliths of 11 species of $\mathrm{Lu}$ tjanus from the central Great Barrier Reef. Fisheries Bulletin 98:474-484.

Choat, J. H., and L. M. Axe. 1995. Growth and longevity in acanthurid fishes: an analysis of otolith increments. Marine Ecology Progress Series 134:15-26

Choat, J. H., and D. R. Robertson. 2002. Age-based studies. Pages 57-80 in P. F. Sale, editor. Coral reef fishes: dynamics and diversity in a complex ecosystem. Academic Press, San Diego, California, USA.

Cole, R. G., E. Villouta, and R. J. Davidson. 2000. Direct evidence of limited dispersal of the reef fish Parapercis colias (Pinguipedidae) within a marine reserve and adjacent fished areas. Aquatic Conservation: Marine and Freshwater Ecosystems 10:421-436.

Cowen, R. 2002. Larval dispersal and retention and consequences for population connectivity. Pages 149-170 in P. F. Sale, editor. Coral reef fishes: dynamics and diversity in a complex ecosystem. Academic Press, San Diego, California, USA. 
Davidson, R. J. 2001. Changes in population parameters and behaviour of blue cod, (Parapercis colias: Pinguipedidae) in Long Island-Kokomohua Marine Reserve, Marlborough Sounds, New Zealand. Aquatic Conservation: Marine and Freshwater Ecosystems 11:417-435.

Dayton, P. K., E. Sala, M. J. Tegner, and S. F. Thrush. 2000. Marine protected areas: parks, baselines, and fishery enhancement. Bulletin of Marine Science 66:617-634.

DeMartini, E. E. 1993. Modelling the potential of fishery reserves for managing Pacific coral reef fishes. Fishery Bulletin 91:414-427.

Eristhee, N., and H. A. Oxenford. 2001. Home range size and use of space by Bermuda chub, Kyphosus sectatrix (L.), in two marine reserves in the Soufriere marine management area, St. Lucia. Journal of Fish Biology 59:129-151.

Froese, R., and D. Pauly. 1997. Fishbase 97: concept, design and data sources. International Center for Living Aquatic Resources Management, Manila, Philippines.

Gaines, S. D., B. Gaylord, and J. L. Largier. 2003. Avoiding current oversights in marine reserve design. Ecological Applications 13(1):S32-S46.

Galal, N., R. F. G. Ormond, and O. Hassan. 2002. Effect of a network of no-take reserves in increasing catch per unit effort and stocks of exploited reef fish at Nabq, South Sinai, Egypt. Marine and Freshwater Research 53:199-205.

Gell, F. R., and C. M. Roberts 2002. The fishery effects of marine reserves and fishery closures. World Wildlife FundUnited States, Washington, D.C., USA.

Gerber, L. R., L. W. Botsford, A. Hastings, H. P. Possingham, S. D. Gaines, S.R Palumbi, and S. Andelman. 2003. Population models and marine reserve design: a retrospective and prospective synthesis. Ecological Applications 13: S47-S64.

Hilborn, R. 2002. Marine reserves and fisheries management-Reply to C.M. Roberts. Science 295:1233-1234.

Holland, K. N., J. D. Peterson, and B. M. Wetherbee. 1993. Movements, distribution and growth rates of the white goatfish Mulloides flavolineatus in a fisheries conservation zone. Bulletin of Marine Science 52:982-992.

Jackson, J. B. C. et al. 2001. Historical overfishing and the recent collapse of coastal ecosystems. Science 293:629638.

James, M. K., P. R. Armsworth, L. B. Mason, and L. Bode. 2002. The structure of reef fish metapopulations: modelling larval dispersal and retention patterns. Proceedings of the Royal Society of London B 269:2079-2086.

Kelleher, G., C. Bleakley, and S. Wells. 1995. A global representative system of marine protected areas. Volumes 14. Environment Department, The World Bank, Washington, D.C., USA.

Kelly, S., D. Scott, and A. B. MacDiarmid. 2002. The value of a spillover fishery for spiny lobsters around a marine reserve in northern New Zealand. Coastal Management 30: 153-166.

Kramer, D. L., and M. R. Chapman. 1999. Implications of fish home range size and relocation for marine reserve function. Environmental Biology of Fishes 55:65-79.

Maypa, A. P., G. R. Russ, A. C. Alcala, and H. P. Calumpong. 2002. Long-term trends in yield and catch rates of the coral reef fishery at Apo Island, central Philippines. Marine Freshwater Research 53:207-213.

McClanahan, T. R., and B. Kaunda-Arara. 1996. Fishery recovery in a coral-reef marine park and its effect on the adjacent fishery. Conservation Biology 10:1187-1199.

McClanahan, T. R., and S. Mangi. 2000. Spillover of exploitable fishes from a marine park and its effect on the adjacent fishery. Ecological Applications 10:1792-1805.
NRC [National Research Council (USA)]. 2001. Marine protected areas: tools for sustaining ocean ecosystems. National Academy Press, Washington, D.C., USA.

Palumbi, S. R. 2001. The ecology of marine protected areas. Pages 509-530 in M. D. Bertness, S. D. Gaines, and M. E. Hay, editors. Marine community ecology. Sinauer, Sunderland, Massachusetts, USA.

Pauly, D., V. Christensen, J. Dalsgaard, R. Froese, and F. Torres. 1998. Fishing down food webs. Science 279:860863.

Pauly D., V. Christensen, S. Guénette, T. Pitcher, U. R. Sumaila, C. Walters, R. Watson, and D. Zeller. 2002. Towards sustainability in world fisheries. Nature 418:689-695.

Polacheck, T. 1990. Year round closed areas as a management tool. Natural Resources Modelling 4:327-354.

Rakitin, A., and D. L. Kramer. 1996. Effect of a marine reserve on the distribution of coral reef fishes in Barbados. Marine Ecology Progress Series 131:97-113.

Roberts, C. M., J. A. Bohnsack, F. Gell, J. P. Hawkins, and R. Goodridge. 2001. Effects of marine reserves on adjacent fisheries. Science 294:1920-1923.

Roberts, C. M., and J. P. Hawkins. 2000. Fully-protected marine reserves: a guide. Endangered Seas Campaign, World Wildlife Fund- United States, Washington, D.C., USA.

Roberts, C. M., and N. V. C. Polunin. 1991. Are marine reserves effective in management of reef fisheries? Reviews in Fish Biology and Fisheries 1:65-91.

Russ, G. R. 2002. Yet another review of marine reserves as reef fisheries management tools. Pages $421-443$ in P. F. Sale, editor. Coral reef fishes: dynamics and diversity in a complex ecosystem. Academic Press, San Diego, California, USA.

Russ, G. R., and A. C. Alcala. 1996. Do marine reserves export adult fish biomass? Evidence from Apo Island, central Philippines. Marine Ecology Progress Series 132:1-9.

Russ, G. R., and A. C. Alcala. 1998. Natural fishing experiments in marine reserves 1983-1993: community and trophic responses. Coral Reefs 17:383-397.

Russ, G. R., and A. C. Alcala. 1999. Management histories of Sumilon and Apo marine reserves, Philippines, and their influence on national marine resource policy. Coral Reefs 18:307-319.

Russ, G. R., A. C. Alcala, and A. S. Cabanban. 1992. Marine reserves and fisheries management on coral reefs with preliminary modeling of the effects on yield per recruit. Pages 988-995 in R. H. Richmond, editor. Proceedings of the Seventh International Coral Reef Symposium. Volume 2. University of Guam Marine Laboratory, Mangilao, Guam.

Russ, G. R., and D. C. Zeller. 2003. From Mare Liberum to Mare Reservarum. Marine Policy 27:75-78.

Underwood, A. J. 1981. Techniques of analysis of variance in experimental marine biology and ecology. Oceanography and Marine Biology Annual Review 19:513-605.

Walmsley, S. F. 2000. Ecological effects of marine sanctuaries and the influence of community, management and enforcement factors on their success. Thesis University of Newcastle-upon-Tyne, Newcastle-upon-Tyne, UK.

White, A. T., C. A. Courtney, and A. Salamanca. 2002. Experience with marine protected area planning and management in the Philippines. Coastal Management 30:1-26.

White, A. T., and G. C. Savina. 1987. Reef fish yield and non-reef catch of Apo Island, Negros, Philippines. Asian Marine Biology 4:67-76.

Winer, B. J. 1971. Statistical principles in experimental design. McGraw-Hill, New York, New York, USA.

Zeller, D. C., and G. R. Russ. 1998. Marine reserves: patterns of adult movements of the coral trout Plectropomus leopardus (Serranidae). Canadian Journal of Fisheries and Aquatic Sciences 55:917-924. 